The final, definitive version of this paper has been published in Feminist Theology, Vol. 25(2), 2017, pp. 208-221, by SAGE Publications Ltd, All rights reserved. (C) [The Author] https://doi.org/10.1177/0966735016679907

To cite this article: Pérez-Gil, María del Mar. "Undressing the Virgin Mary: Nudity and Gendered Art”. Feminist Theology 25.2 (2017): 208-221.

https://doi.org/10.1177/0966735016679907

\title{
Undressing the Virgin Mary: Nudity and Gendered Art
}

\begin{abstract}
Stripping the Virgin Mary of the myths, stories, and dogmas surrounding her is a task that has particularly appealed to a branch of feminist theology which seeks to reclaim her as a figure of female empowerment. This article aims to explore the transformation of Mary's body into an element of resistance in the work of some contemporary artists. By depicting her nude or seminude, artists disrupt the gender values commonly associated with the Virgin and open up alternative possibilities of affirmative selfhood through her body. I contend that, in these works, the Virgin's body functions as a 'relational' body that enters into dialogue with hitherto marginalized categories, such as the carnal, the sensual, the notion of fleshly materiality, or even the excluded sexualities of transgender people.
\end{abstract}

\section{Keywords}

Virgin Mary, nudity, ideologised body, corporeality, identity, transgender

Sexuality and the nude body are often seen by Christians to be inimical to the notion of sacredness. Over the centuries, Mary's body has grown in virtue through the continued negation of her flesh. Visually, the Virgin's 'sites of gynecological power' are masked by 'an abundance of sumptuous clothing' (Caviness 2001: 2) which conveys the impenetrable mystery of God becoming flesh in her. In written narratives, Mary's body is clothed with a sumptuous mass of similes and metaphors that elevate her beyond the ordinary. In calling Mary a rose, a closed garden, a vessel of purity and other such 
expressions, writers deny the materiality of her body, which disappears into a virginal rhetoric of incorporeal tropes.

This article approaches the Virgin's body as a medium that reflects dominant discourses of power and sexuality and, as I seek to show, the struggle against them. ${ }^{1} \mathrm{I}$ will explore how contemporary depictions of a nude or seminude Virgin Mary open up alternative possibilities of affirmative selfhood through her body. My main focus of analysis is those artworks in which issues of gender are the primary concern. After initial consideration of questions of agency and representation in art, I will examine the ideological base underlying the visual renditions of Mary. In the second part, I will analyse some of the works that give visibility to her nude body and will look into the reasons behind such a redefinition of her figure in contemporary art. I contend that, in these works, Mary's body functions as a 'relational' body, in opposition to the sealed body she has been made to epitomize. Her body opens into dialogue with hitherto marginalized categories, such as the carnal, the sensual, the notion of fleshly materiality, or even the excluded sexualities of transgender people.

\section{The 'who's and how's' of representation}

Marina Warner argues that prayers 'formed the figure of the Virgin Mary' (1990: 285); for centuries, art has played a similar role in fashioning an archetypal image of her. Litanies, hymns, poems, paintings, and popular icons have all raised Mary to still greater dignity and perfection. She comes to us as the quintessential embodiment of sexual chastity, moral virtue and selfless motherhood, an image that art has actively and effectively contributed to spread. Her body conveys doctrinal and gendered meanings from head to foot: her beauty, her expression, her downcast eyes, the position of her hands, the child she holds - or holds not — her face tenderly bent on him, her posture, her loose hair, ${ }^{2}$ what we occasionally see (her breast), and what remains covered become powerful signifiers.

1 Some feminist theologians have pioneered the task of recovering Mary from the patriarchal grasp of the traditional interpretations. See Ruether 1993, Beattie 2002, and Johnson 2009. These theologians seek to reclaim Mary as a figure of female empowerment. My article investigates this aspect from an embodied perspective.

2 The fact that Mary's hair is covered symbolizes her modesty and virginity, but so does also her loose hair. Loose hair "was always a specifically sexual reference, the sign of female emotional looseness ... and a standard sexual invitation-Mary Magdalene wears it. But respectable unmarried girls, just like the Virgin Mary, wore loose hair to suggest the power of absolute female chastity' (Hollander 1994: 56). 
For Nicholas Mirzoeff, the body in art is a 'sign' that represents 'both itself and a range of metaphorical meanings' (1995: 2). The body in art and the 'real' body are not the same thing. The perfect body-Mirzoeff explains - exists only as a visual representation. For example, the magnificent portraits of absolutist kings are imperative in achieving the image of splendour and perfection of the body politic. Similarly, 'the mother of Jesus, an obscure figure who rated only four mentions in the Gospels, became the Virgin Mary through the transmission and dissemination of the Madonna icon' (1995: 3). Artists create a symbol, an omnipresent 'metaphor' (Caviness 2001: 14) that surpasses the real woman in her purity and grace.

According to Margaret R. Miles, representations are acts of interpretation that replace the real object with its represented form, a process that involves suppressing the real object's complexity: 'Consistent, cumulative, and continuous representations of an object cause that object to "disappear" in its complex and perhaps contradictory "reality", subsumed in the "tidy, well-ordered totality" of the standardized representation' (1992: 10). Representations are ideological acts that reflect existing social practices, beliefs, attitudes, prejudices and stereotypes, but they also serve to produce and 'perpetuate' them (1992: 11). Miles observes that the questions that should be asked when it comes to the matter of representation are: 'Who has the power of representation in a particular culture? Who can be represented and how?' Reality — says Miles - is grasped 'through representations' alone (1992: 5), and these are instrumental in the elaboration of 'truth'.

It is, precisely, the 'who's' and 'how's' of representation that turn the artistic construction of the Virgin into a strongly politicized act, even when the aim may be solely religious. For instance, in the liturgical art of Fr. Jim Hasse, Janet McKenzie, and Fr. John B. Giuliani in the late nineties and early twenty-first century, Mary 'goes multicultural' and is represented as an Afro-American, an Oriental or a Native American dressed in Comanche, Navajo, Cheyenne, Blackfoot, or Aymara costumes. These works are imbued with a deep spirituality which contrasts with the politicallycompromised position of other artists. In Zapatista Virgin (2001), Eduardo Díaz depicts the Virgin of Guadalupe dressed in peasant clothes. She stands in a church niche, has naked feet, and wears a balaclava. Renée Cox and Clecio Lira address questions of race and/or gender, as do also Antonia Rolls and Mary Ellen Croteau, who blatantly play on humour and irony in their works. The first-mentioned examples - those privileging race and ethnicity — remain acceptable for Christians as long as artists depict the Virgin as a 
symbol of purity and motherly love. In fact, images of this kind have assisted the Church in its evangelizing task and are found in many countries around the world. In contrast, those renditions grounded in gender are more likely, if not doomed, to be considered offensive and sacrilegious.

For Elizabeth Grosz, the body is a 'page ... ready to receive, bear, and transmit meanings, messages, or signs' (1994: 117). Mary's body is no exception to this; rather, she is a most appropriate example with which to illustrate Grosz's ideas. Grosz argues that bodies are a surface on which meanings are inscribed. There are no 'ahistorical', 'precultural' or 'natural' bodies; social, cultural and historical demands always 'produce the body as a body of a determinate type' (1994: $\mathrm{x}$ ). This is truer in the case of the female body, a site of struggle in which the issues involved are 'the activity and agency, the mobility and social space, accorded to women' (1994: 19).

Theologians have long struggled to possess Mary's body and to circumscribe it within definitional limits. Her body is turned into a disciplinary object, a homiletic body through which other 'docile bodies' may be produced, out of hers and in imitation of hers. What Mary did with her body - and the things she never did because it was not in her 'nature' - determine the cultural value that Western society assigns to such a notion as female decency. For many generations of women, Mary has been a panoptical figure who keeps incessant watch over their behaviour and sexual conduct. As the British novelist Hilary Mantel puts it: 'In my Catholic girlhood [Mary] was everywhere, perched up on ledges and in niches like a CCTV camera, with her painted mouth and her painted eyes of policeman blue ... she knew your every move' (2009: 3).

According to Sarah Jane Boss and Tina Beattie, the Virgin Mary has been increasingly distanced from the notion of embodied divinity she personifies. Boss explains that the Madonna lactans (or breast-feeding Virgin) was a widespread motif in many paintings during the fourteenth and fifteenth centuries, after which it gradually started to disappear so that, from the eighteenth century onwards, these representations became almost non-existent in art: a 'nursing Virgin in the twentieth century would be either shockingly sexual, or inappropriately medical' (2000: 38). This theologian argues that the prominence given in the past to the Virgin's role as mother and Queen of Heaven was replaced by a 'modern' conception of Mary that celebrates her submission to God's will by portraying her as a 'humble young girl at prayer' (2000: 15), or, alternatively, as the Immaculate Conception standing alone on the pedestal without her child. The emphasis moved away from the central role that Mary's body plays in the 
incarnation to simply highlighting her moral qualities: 'Physical motherhood has given way to moral purity and authority has been displaced by humility' (2000: 147).

Tina Beattie agrees with Boss and contends that these representations create a picture of Mary 'divorced from the reality of the flesh'. Instead of 'a fully human mother' who gives birth to 'a fully human God', she becomes an 'idealized' and 'transcendent feminized principle' (2007: 298). Beattie says that the Reformation, the Counter Reformation, and modernity brought about a more spiritual vision of religion that turned the focus to Christ's self-sacrifice and death. With the Council of Trent several popular images foregrounding the idea of embodiment fell into disgrace. Paintings and sculptures of Anne and Joachim kissing and embracing each other at the Golden Gate were banned, and those of the Holy Kinship, a familial unit made up of Saint Anne, the Virgin Mary, her two sisters and their children, met the same fate (according to some tradition, Anne was married two other times after Joachim's death [Beattie 2008: 5-6]). The 'fecund Virgin of the medieval imagination' was ultimately 'repressed by a stereotypical image of feminine beauty which deprives Mary of her rich incarnational and relational significance' (Beattie 2008: 19).

Beattie's call for the need to re-envision Mary's motherhood as an affirmation of the doctrine of the incarnation and the 'inherent goodness of the material world and human flesh' (2007: 298) finds a parallel in the work of some artists, like Bruce Manwaring, Guy Reid, and Edward Knippers. In their incarnational art, Mary's nudity becomes the most palpable sign of the union between the human and the divine. In The Holy Thing (2005), Manwaring portrays a nude Mary in profile. Inside her translucent pregnant womb is a fetus, not fully formed, connected to the placenta by the umbilical cord. The vividly red halo of nurturing blood flowing around Mary's belly highlights the biological nature of the incarnation. She is laughing happily as she looks down on her belly and touches it. An angel's face is juxtaposed with hers, so as to remind us of the narrative of the Annunciation. Manwaring looks back at the origins of Christianity, at the flesh-and-blood woman who grew the Messiah within her body and gave birth to the child-god. This is the woman who takes centre-stage in the painting. Reid's Madonna and Child (2000) is a limewood statue of the nude Madonna with baby Jesus sitting on her knees. The Annunciation (2010), by Knippers, also starts from a material conception of Christianity that gives preeminence to Mary's full humanity (see his painting The Second Coming [1996] for a similar treatment of Christ). 
While the Virgin's nudity in these artworks serves to convey a liturgical messagein fact, the statue by Reid is placed in St Matthew's Church in Westminster, Londonin other works her nudity is tinged with a tone of social denunciation. The next section constitutes an exploration of this subject.

\section{Undressing Mary}

For the French philosopher Luce Irigaray, Christian orthodoxy obliterates the inherent sacredness of the human flesh by instituting the belief in a 'suprasensory' God (1991: 186) who remains distant from the body's materiality:

Who interpreted him in this way? Who abominated the body so much that he glorified the son of man for being abstinent, castrated? And why was it necessary for Christ to die and rise again in order for men to believe he was God? Why could his presence in the flesh not be perceived as divine? (1991: 177)

Like Christ, the Virgin Mary must remain sexually abstinent for her to be considered 'divine'. Not only do her clothes mark her exile from the inviolable mystery that is her body, but also the suprasensory language through which her sanctity is constructed delivers her from the taint of the physical. This celibate language that writers attain by poetic elevation distances the referent (the body) from its innate materiality by projecting the former into a world of sweet fragrances, floral delicacy, and architectural elements that suggest the idea of spatial enclosure. Similes and metaphors objectify Mary's body and deliberately circumvent the biological femaleness that brings her into a corporeal unity with other women: she is a 'fragrant rose', a 'lily of chastity', a 'shut gate', and a 'garden enclosed'; her womb is a granary, an oven, a tabernacle, and a temple. This rhetoric contrasts with the gynecological language employed in some recent scholarly works in which words undress Mary by calling her secret female anatomy by its proper name. In her book Corporal Knowledge: Early Christian Bodies, Jennifer A. Glancy talks of Mary's 'genitalia', 'labia', and 'perineum' (2010: 82, 83, 84), as do other theologians and scholars who refer to the Virgin's sexed body by using such terms as 'vagina', 'clitoris' and 'vulva' (Althaus-Reid 2000: 39, 73; Peraino 2006: 46; Ribas 2006: 135; Waller 2011: 36). 
In a revealing essay published in 2006 about the influence of religious iconography on the consolidation of gender stereotypes in Latin America, the Brazilian theologian Mario Ribas advocates the necessity of undressing Mary as a way of liberating her from a discourse that acts as a 'source of repression' for women:

Undressing Mary ... does not necessarily mean producing her as an object of sexual desires, but rather bringing back awareness of the body and sexuality as a way to liberate those who have found themselves alienated and oppressed by the current social and economic structures which are legitimized by the religious discourse and symbols. (2006: 131)

Ribas's liberation of Mary vindicates a genuinely incarnational Christianity that does not exclude - or put shame on — sexuality but considers it an integral part of the human being. His proposal seeks to give visibility to the female body as a means of recovering the dignity of women and the oppressed. Ribas states that the popular religious iconography functions as an 'instrument of control' (2006: 124) upon the masses, especially the poor, and exerts a strong influence on the formation of their cultural values and the perpetuation of the structures of social and religious power. This iconography serves to uphold a patriarchal ideology. The statues of the Virgin-Ribas contends - give visual support to the ideal of the 'perfect and decent woman': 'The icons and portraits of Mary always represent her as a young woman, overdressed and for the most part entirely naïve. The outcome is the image of an asexualized woman whose body is hidden by layers of theological concepts which impose virginity upon her and deny her as sexual being' (2006: 128). This denial of sex becomes a source of oppression for both 'decent' and 'indecent' women. Those whose sexual demeanour is considered indecent (single mothers, prostitutes, and sexually liberated women) may feel alienated from Mary, since they regard themselves as sexually 'impure' according to the dominant moral standards.

Arguably, the notion of 'undressing' Mary, or even of revealing certain parts of her body, is the surest way to trigger scandal and disapproval among some. Opinions have not changed all that much over time. In seventeenth-century Spain, for instance, Francisco Pacheco thanks the Holy Inquisition for correcting the liberties taken by some painters who depict the Virgin with her legs crossed and her 'sacred feet uncovered and naked' (1866: 249). In the eighteenth century, Juan Interián de Ayala demands that 
nudity and all other indecencies be avoided in devotional art. He abhors those paintings that show the Virgin's 'most pure and virginal breasts' and depict her with her fair hair loose and with naked shoulders and neck, which makes her resemble the Venus of Cnidus or a pagan goddess, he says. Interián de Ayala severely objects to the portrayal of stark naked angels - they look to him more like 'provocative and dishonest little Cupids' (1782: 25) — and warns against the libidinous desires that the images of nude saints and martyrs may arouse in men as well as in women, even those who have purest minds.

These opinions expressing disturbance at the vision of Mary's flesh are not so foreign to our time. A well-known example is the mixed media collage Walking Guadalupe (1978) by the feminist Chicana artist Yolanda M. López. In it, the Virgin is walking in heeled sandals and is wearing a dress that reaches down to her knees. In a talk given in 2001, López claimed that this work was meant to liberate the Virgin of Guadalupe from the 'bondage' of the clothes and mantle in which she is 'trapped' in the original canvas (quoted in Keller et al. 2002: 80). When the Mexican feminist magazine Fem reproduced the walking Guadalupe on the cover of one of its 1984's issues, the editorial office received a bomb threat (Zires 2005: 96).

Several years later, another revisionary work — again by a Chicana artist — caused a still hotter and angrier debate. Our Lady (1999), a digital composition by Alma López, met with an irate response when exhibited in the Museum of International Folk Art in Santa Fe, New Mexico. López violates the canon by depicting the Virgin of Guadalupe half-nude. In fact, she is wearing only a mantle and a bikini of roses and leaves. Her arms are akimbo and she has a bold look in her eyes. The half-crescent moon on which she is standing is supported by a bare-breasted woman with butterfly wings. A number of people were scandalized at this work and insisted that it should be removed from the museum. They accused Alma López of sacrilege and poured insults on the model posing for her. Verbal abuse was heaped on the curator, Tey Marianna Nunn, who reports that she and López received death threats (2011: 31): 'Those of us directly involved were the recipients of many threatening phone calls, menacing letters, and personal attacks. ... It was declared that I was starting a new religion and promoting Satanism' (2011: 30).

Issues of gender, sexuality, female agency, and identity concur in the composition by López, whose purpose was solely to question the cultural negativity surrounding the female body, along with the normative passivity and submission expected of women 
through the example set by the Virgin. López responded categorically to the controversy generated by her work. The very act of removing it from the museum, she said, would imply

that there must be something wrong and sexually perverted with my female body. It means that it's okay for men to look at our bodies as ugly ... It means that only men can tell us how to look at La Virgen. It means that we cannot look upon La Virgen as an image of a strong woman like us. (2011: 16)

López's collage transforms the Virgin of Guadalupe into a symbol of beauty, power, sensuality, and sacredness. She is both Eve in the Garden of Eden and the Virgin of Guadalupe, much of whose beauty and allure reside in her sensuality. The Virgin is not supported by an angel (as happens in the original canvas) but by another flesh-andblood woman. The composition is colourful and vibrant. It celebrates womanhood and vindicates the beauty of the female body. Women's bodies are not 'ugly and perverted', López claims (2011: 15); on the contrary, they are 'gifts from our creator' (2011: 14).

This holistic approach to woman which makes Eve one with Mary through the body is also present in Love goddess (1978) by Yolanda M. López. The artist utilizes the symbols of two conflicting mythologies - the Christian and Roman - and the two iconic figures representing love: the Virgin and Venus. Each of these women embodies a polar conception of love as agape and eros, respectively, and each is aligned with a fixed, essentialist notion of the female self and body. López confronts this gender binarism by superimposing the image of one woman on that of the other and producing a syncretistic female figure whose face and nude body are those of Botticelli's Venus. She is covered with Guadalupe's mantle and her mandorla is at the back.

While López's work may convey the repression of the sexual body by a more spiritual view of religion and love epitomized by the Virgin of Guadalupe, the technique of superimposition allows for a more fluid understanding of the concept of woman. By emphasizing inclusivity as a visual practice that resists rigid stereotyping, López's collage transcends the definitional limitations laid on both Guadalupe and Venus. The fact of wearing the Virgin's mantle gives an aura of sacredness to the figure symbolizing eros. Alternatively, the Virgin of Guadalupe can be seen to step off the half-crescent dark moon in order to stand nude on Venus's shell. The birth of the New 
Guadalupe occurs by integrating that which has been excluded. She is the new goddess of love who unites the erotic with the spiritual, or sexual with maternal love.

The Virgin exists within a discourse that negates the other within her, not only sexual but also aesthetic or even ethical. ${ }^{3}$ Ribas contends that Mary is 'always represented as a lady with a perfect complexion, young, slim and, normally, white' (2006: 133). In Virgin Mary (1992), a wax, cheesecloth and wood sculpture, the American artist Kiki Smith strips her of such poetics of the female body. Smith's approach is basically materialistic. She moulds a flesh-and-blood Virgin Mary. Her bald head and unclothed body distance her from the visual construct produced through art, and direct attention to the physicality of her body. Mary's flayed skin is, probably, the most telling feature of the sculpture. Smith disregards the attribute of physical beauty in order to present an alltoo-human woman whose muscles, ligaments, nerves and fibres are partly covered in blood, even to the point of provoking revulsion. This is the Mary of the incarnation, the earthly woman who bore and birthed the divine in and through her body and whom patriarchy slyly robbed of her 'femininity and sex'. ${ }^{4}$ On this woman's body, religion, art, and literature have inscribed myths, stories, miracles, moral and sexual dictums, and dogmas of faith.

Smith opposes the blunt materiality of Mary's body to the canonical veneration of it as bloodless, incorruptible, and pure flesh. As Helaine Posner argues, quoting the artist's words: 'For Smith, the Virgin Mary is most beneficial as a role model when she is incarnated "insistently and defiantly in the flesh"" (2005: 23). Such an approach to the Virgin promotes a relationship between her and women based on the notion of biological parity (see Pérez-Gil 2011). Mary's open, receptive hands are the element that brings Smith's sculpture closer to classical representations. For the rest, the Virgin is disrobed of all the other visual, religious, and cultural prostheses that she traditionally wears. More problematically, Smith's Virgin Mary confronts the viewer with what might be only a religious myth, a gender fabrication, and the illusion of a transcendent and divine being who cares for us.

3 In La Vierge corrigeant l'enfant Jésus devant trois témoins (1926), the surrealist painter Max Ernst depicts the Virgin briskly spanking the infant Jesus, whose halo lies on the ground. Noticeable for their break from the canon of beauty are Fernando Botero's Madonnas. Our Lady of New York (1966) and Our Lady of Cajica (1972) are excessively overweight Madonnas, as usual in Botero.

${ }^{4}$ 'The position of the Virgin robs you of your femininity and sex' (Smith, quoted in Heartney 2004: 159). 
The nude body of a heavily pregnant woman has not been an inspiration for many artists, and neither has been the moment of birth. Not so long ago, the pregnant belly was 'disguised ... and shrouded in silence under the folds' of 'bubbly and ballooned' clothes (Trakas 2009: 53, 58). Annie Leibovitz's photograph of a pregnant Demi Moore on the August 1991 cover of Vanity Fair marks a before and after in the aesthetic reception of the pregnant body. Realistic paintings of heavily pregnant nude women are no longer artistic anathema. Mention should be made of artists Paul Matthews-Waiting (1993) and Pregnant Woman Stretching (1994) — and Ron Mueck, with his famous sculpture Pregnant Woman (2002). Furthermore, Matthews and Mueck make the process of child delivery the central focus of other works, as happens in Matthews's Crowning (1995) and Mueck's Mother and Child (2001).

In I.N.R.I. (1998), a series of photographs that achieved worldwide notoriety with their polemical revision of the Gospels, Bettina Rheims breaks fresh ground in the representation of the pregnant Virgin. I.N.R.I. re-creates some of the most important episodes in Jesus' life and transposes them into a contemporary setting - two thousand years after his birth. The figure of a nude Mary appears in several of the photographs. One of them, titled La Visitation (1997), portrays the Virgin showing off her heavily pregnant belly. The scene enacts Mary's visit to her cousin Elizabeth, an encounter reproduced in numerous artworks. In the traditional canon, both women usually stand in profile. They are fully dressed and their mantles strategically hide the pregnancy. The importance resides in the visit, in the meeting of the two women and the happy news that Mary will share with her cousin. Both women touch or embrace each other as a sign of greeting, or, alternatively, they walk toward each other. In other works, Mary's and Elizabeth's pregnant bellies are clearly noticeable and, also, the haloed babies in their womb. Often, Mary's head is slightly bent.

These representations replace the female semiotics of the body with the language and meanings of the symbolic. The symbolic constructs Mary's maternity as a textual dogma of faith and an emblem of purity. Earlier in my essay, I argued that the poeticized body of the Virgin functions to distance her from the vocabulary of the abject that designates other women's bodies. The 'masculinist' production of knowledge that sustains the symbolic, as Robyn Longhurst says, is rooted in discourse and theory, both of which 'offer a purity that materiality and practice threatens to taint and soil' (2001: 2). The logocentric language and imagery of the symbolic transforms the Virgin's 
pregnant body into a metaphor of sacredness that manifests itself as a body visually contained by clothes and within the prescribed representational rules of artistic tradition.

Rheims chooses instead to portray pregnancy in all its glorious corporeality. Her embodied, and subversively semiotic, view of Mary's pregnancy opens new paths in the artistic treatment of the Visitation scene. Mary and Elizabeth are photographed in a frontal pose as they proudly show off their full, rounded bellies, which occupy a central position. Mary is wearing only a satin bra and a long blue skirt that reaches down to her feet. She is smiling, while Elizabeth smiles at her in seeming complicity. The photograph was taken in the psychiatric hospital of Ville-Évrard, a location charged with meaning considering how people would react, two thousand years later, to a miraculous pregnancy.

Rheims's incarnational portrayal of pregnancy brings Mary and Elizabeth into a sororal or semiotic relationship with other women that originates in the biologization of their bodies. Mary is more flesh than spirit. The symbolic order, which Julia Kristeva defines as the sphere of language and masculine reason, stands in opposition to the semiotic order, a pre-Oedipal and pre-linguistic stage associated with the mother. For Andrea Nye, motherhood in the semiotic stage is tantamount to a 'union/reunion between bodies, a union in which there is no logical structure but a whirl, a flux of feeling and expression' that the symbolic tries to "“seal off" and "censure"” (1989: 143). In Rheims's photograph, pregnancy is part of the halo of power and self-sufficiency surrounding Mary and Elizabeth. The photograph evokes the notion of female friendship, empowerment, jouissance, and mutual understanding. Borrowing from Hélène Cixous, both women take pleasure in 'being boundless'. Mary's body is 'explosion, diffusion, effervescence, abundance' (1997: 163). She symbolizes bodily excess, rather than containment. And, yet, such embodied excess is also the source of her beauty.

In the last part of this section, I would like to focus on a more radical redefinition of Mary's body that connects her with aspects of queer sexuality. According to Marcella Althaus-Reid, 'theology has been and will remain a sexual praxis' (2004: 100). The construction of sexuality and gender has been historically influenced by predominantly religious beliefs that determine what is normal and what deviant. Traditional theologies - says Althaus-Reid - are sexual theologies that create 'hegemonic sexual systems' (2003: 4). These systems support a particular socioeconomic structure and marginalize those sexual orientations and practices that may destabilize the existing 
order. For the Argentinean theologian Martín Hugo Córdova Quero, 'there is no such thing as innocent theology'. Every 'theology is, in fact, ideology' (2006: 82). Córdova Quero explains that traditional theology privileges a binary structure that determines how gender and sexuality are culturally understood. Difference, and everything that does not adhere to the accepted standards of decency, is marked negatively as deviant and is marginalized (2006: 81).

For Córdova Quero, conventional theology complies with 'body fascist ideologies' (2008: 84) that discriminate people by reason of their sexual orientation or ambiguous gender identity. Body fascism and heteronormativity regulate the construction of the ideal body in society. The perfect body rules out 'other body/ies that are considered deviant' (2008: 83) because they do not conform to the approved model. Homosexuals, bisexuals, transgender people, and similar other alternative constructions of gender, are excluded from the category of the normal. Body fascism functions to police and control these groups and subject them to discrimination and punishment. Discursive 'technologies of other/ring' such as 'stigmatization, labeling, dehumanizing, demonizing and silencing' (2008: 90) are used against these individuals. Notably, Córdova Quero regards silencing as one of the 'most insidious ways' of marginalization, 'since it makes people invisible' (2006: 98).

Artworks informed by a homosexual or transgender theological perspective began appearing in the 1980s and reflect these groups' critique of the Catholic Church's politics of gender segregation. Some of the artists that have given visibility to queer sexualities are Nahum B. Zenil in Gracias Virgencita de Guadalupe (1984), which shows the artist and another man lying nude in bed, while the image of the Virgin looks down on them; Alex Donis, who depicts Mary Magdalene kissing the Virgin of Guadalupe in the mouth in his series My Cathedral (1997); Elisabeth Ohlson Wallis, in Ecce Homo (1998); Alma López, in Lupe and Sirena in Love (1999); James Ru, in Virginia Guadalupe, Drag Queen of Compassion (n.d.), in which a crowned drag queen features as the Virgin; and the French artist Soasig Chamaillard in Embrasser (2010), a sculpture in which two Virgin Marys kiss each other, their heads and bodies forming a heart with the colours of the rainbow flag.

Bearback Yes, Bareback No: Bears Against AIDS (2010), a calendar financed by a LGBT association in Madrid in order to promote the use of condoms and prevent the spreading of AIDS, contains a series of photographs by the Venezuelan artist Juan Antinoo that serve as a visual illustration of what Althaus-Reid calls 'indecent 
theology'. Antinoo approaches the imaginary of gender deviance through individuals whom religious art excludes from representation and the iconography of the sacred. His photographs are provocative, yet charged with a profound social message against the Church's views concerning the use of prophylactics.

The image of the Virgin appears in all the months of the calendar. Traditionally, Mary personifies an essentialist idea of gender linked to a fascist conception of the body that conflates her with the true feminine. Antinoo inscribes alternative meanings on her body that fight the etiology of religious and moral discrimination based on notions such as sexual purity or the 'divinely ordained' correlation between sex and gender. In the great majority of the photographs, the models posing as the Virgin are transsexuals and drags. Having them embodying the figure of Mary destabilizes the heterosexual normativity of representation. The actress and activist Carla Antonelli, who posed as the Virgin of Fatima for the month of May, responded conclusively to the controversy about who can, and cannot, model as the Virgin. She said: 'Why is it that a transsexual woman can't represent a religious icon given life by so many other actors and actresses throughout history? To not do it would be akin to internalizing the same discriminatory principles that people want to throw against us'.5

In three of the photographs, Mary is half nude. In the photograph for the month of November, a beautiful trans woman poses as Our Lady of the Miraculous Medal. She is wearing a white laced bikini of condoms, and a white mantle partly covers her head and shoulders, but the rest of her body, including her breasts, is exposed. Rays of light emanate from her hands, and a halo surrounds her head. A regressive view of gender aligned with social and religious conventionalisms pathologizes trans people as abnormal and deviant. As Robert Phillips says, transgender bodies, much like homosexual identities, are elements of defiance that threaten - and cause fear to - the established order, since they do not abide by the culturally constructed notions of sex and gender (2014: 20). It is for this reason that the pathology of abjection is employed against these groups. Antinoo's aesthetic photograph of a nude trans woman succeeds in breaking with the canon of heteronormativity that associates the abject body with monstrosity.

\footnotetext{
${ }^{5}$ Quoted in McBee, 2009. Antonelli's words appear in the article "VVírgenes" transexuales' by Marta Belver, initially published in the Spanish newspaper El Mundo (17 October 2009).
} 
In Art and Obscenity, Kerstin Mey argues that the existing cultural regulations, rather than the natural qualities of an object, determine what is obscene in a particular society. For Mey, the category of the obscene has been instrumentalized in order to safeguard a particular system of social and religious beliefs. Thus, the purpose behind obscenityshe maintains - is to resist 'dominant social norms and hierarchies, and oppressive regimes of discipline and control' (2007: 2). While it is true that Mey's arguments about obscenity cannot be generalized to all artworks, her words convey how terms such as 'the obscene' and 'the blasphemous' have been - and are still being - used in order to shun critical dialogue with those people excluded into the space of the irreverent.

\section{Conclusion}

According to Margaret Miles, women should try to achieve 'self-representation' in art because, if they do not, they run the risk of being misrepresented (1992: 170). Although Miles observes that self-representation is 'an instrument for producing empowerment' (1992: 171), she is, for the most part, pessimistic about the use of the (naked) female body as a means to attain subjecthood, given the negative associations between woman and the body and the fact that female nudity in art has often been perspectivized through the male gaze. In the Christian West, Miles explains, 'female nakedness' has been used as a 'cipher for sin, sex, and death' (1992: 12-13).

Unlike Miles, I believe that the notion of 'undressing' the Virgin in the examples provided offers more constructive grounds for women's self-affirmation, or that of transgender people. Fighting against the religious prejudices that condemn the depiction of a nude Mary as something offensive and blasphemous, the artists studied promote a new relationship with her based on the body. Her nude body suggests alternative relational possibilities that foster the idea of mutuality. Additionally, the sensual beauty of Mary's body, which artists like Alma López and Yolanda M. López portray in their works, blurs the boundaries between the sacred and the sexual and brings the first closer to female corporeality.

Córdova Quero contends that Christianity has to open itself to 'new contexts, body/ies, genders and sexualities' (2008: 102). Like him, other theologians and scholars argue that the patriarchal construction of gender that the Church continues to perpetuate is 'gone or fading' in present-day society (Hamington 1995: 26). The imaginary of irreverence in these artists' works is a mirror to the social and cultural changes regarding women, gender and, more generally, the perception of the body. In this 
article, I have tried to show how a revisionary theological aesthetics of the flesh transubstantiates the Virgin's body into an element of resistance, contrary to its mainstream use as a catalyst for compliance. The dissenting aesthetics proposed by these artists disrupts the standardized forms of representation of Mary, but more important than this, it talks of the need to remove the barriers of sex, gender, and the body that nowadays still prevent a more inclusive understanding of religion.

\section{References}

Althaus-Reid M (2000) Indecent Theology: Theological Perversions in Sex, Gender and Politics. New York: Routledge.

Althaus-Reid M (2003) The Queer God. London: Routledge.

Althaus-Reid M (2004) Queer I stand: lifting the skirts of God. In: Althaus-Reid M and Isherwood L (eds.) The Sexual Theologian: Essays on Sex, God and Politics. London: T\&T Clark, 99-109.

Beattie T (2002) God's Mother, Eve's Advocate: A Marian Narrative of Women's Salvation. London: Continuum.

Beattie T (2007) Queen of heaven. In: Loughlin G (ed.) Queer Theology: Rethinking the Western Body. Oxford: Blackwell, 293-304.

Beattie T (2008) 'Let nature leap for joy, and let women be honoured': historical developments in Catholic Marian symbolism. Paper given at the conference 'The place of Mary in the Christian traditions', Sarum College, Salisbury, in December, 128. Available at: https://sites.google.com/site/tinabeattie/papers2

Boss SJ (2000) Empress and Handmaid: On Nature and Gender in the Cult of the Virgin Mary. London: Cassell.

Bramly S and Rheims B (1998) I.N.R.I. Munich: Gina Kehayoff Verlag.

Butler J (1997) The Psychic Life of Power: Theories in Subjection. Stanford: Stanford University Press.

Caviness MH (2001) Visualizing Women in the Middle Ages: Sight, Spectacle, and Scopic Economy. Philadelphia: University of Pennsylvania Press.

Cixous H (1997 [1975]) Sorties: out and out: attacks/ways out/forays. In: Schrift AD (ed.) The Logic of the Gift: Toward an Ethic of Generosity. New York. Routledge, 148-173. 
Córdova Quero MH (2006) The prostitutes also go into the kingdom of God: a queer reading of Mary of Magdala. In: Althaus-Reid M (ed.) Liberation Theology and Sexuality. Aldershot: Ashgate, 81-110.

Córdova Quero MH (2008) This body trans/forming me: indecencies in transgender/intersex: bodies, body fascism and the doctrine of the incarnation. In: Althaus-Reid MM and Isherwood L (eds.) Controversies in Body Theology. London: SCM, 80-128.

Glancy JA (2010) Corporal Knowledge: Early Christian Bodies. New York: Oxford University Press.

Grosz E (1994) Volatile Bodies: Toward a Corporeal Feminism. Bloomington: Indiana University Press.

Hamington M (1995) Hail Mary? The Struggle for Ultimate Womanhood in Catholicism. New York: Routledge.

Heartney E (2004) Postmodern Heretics: The Catholic Imagination in Contemporary Art. New York: Midmarch Arts.

Hollander A (1994) Sex and Suits: The Evolution of Modern Dress. New York: Alfred A. Knopf.

Interián de Ayala J (1782 [1730]) El pintor christiano, y erudito (trans. L de Durán y de Bastéro). Madrid: Joachín Ibarra.

Irigaray L (1991) Marine Lover of Friedrich Nietzsche (trans. GC Gill). New York: Columbia University Press.

Johnson EA (2009) Truly Our Sister: A Theology of Mary in the Communion of Saints. New York: Continuum.

Keller, GD et al. (eds.) (2002) Contemporary Chicana and Chicano Art: Artists, Works, Culture, and Education; vol. 2. Tempe, AZ: Bilingual Review Press.

Longhurst R (2001) Bodies: Exploring Fluid Boundaries. London: Routledge.

López A (2011) The artist of Our Lady (April 2, 2001). In: Gaspar de Alba A and López A (eds.) Our Lady of Controversy: Alma López's Irreverent Apparition. Austin: University of Texas Press, 13-16.

Mantel H (2009) What did her neighbours say when Gabriel had gone? London Review of Books 31(7): 3-6.

McBee TP (2009) The body electric: trans women subvert religious imagery. 4 November. Available at: https://bitchmedia.org/post/transwomen-subvert-religiousimagery-be-still-my-heart 
Mey K (2007) Art and Obscenity. London: I.B. Tauris.

Miles MR (1992) Carnal Knowing: Female Nakedness and Religious Meaning in the Christian West. Tunbridge Wells: Burns \& Oates.

Mirzoeff N (1995) Bodyscape: Art, Modernity and the Ideal Figure. London: Routledge.

Nunn TM (2011) It's not about the art in the folk, it's about the folks in the art: a curator's tale. In: Gaspar de Alba A and López A (eds.) Our Lady of Controversy: Alma López's Irreverent Apparition. Austin: University of Texas Press, 17-42.

Nye A (1989 [1988]) Feminist Theory and the Philosophies of Man. London: Routledge.

Pacheco F (1866 [1694]) Arte de la pintura, su antigüedad y grandezas. Madrid: Manuel Galiano.

Peraino JA (2006) Listening to the Sirens: Musical Technologies of Queer Identity from Homer to Hedwig. Berkeley: University of California Press.

Pérez-Gil MM (2011) Mary and the carnal maternal genealogy: towards a Mariology of the body. Literature and Theology 25(3): 297-311.

Phillips R (2014) Abjection. TSQ: Transgender Studies Quarterly 1(1-2): 19-21.

Posner H (2005) Kiki Smith. New York: The Monacelli Press.

Ribas M (2006) Liberating Mary, liberating the poor. In: Althaus-Reid M (ed.) Liberation Theology and Sexuality. Aldershot: Ashgate, 123-135.

Ruether RR (1993) Sexism and God-talk: Toward a Feminist Theology. Boston, Mass.: Beacon.

Trakas DJ (2009) The belly beautiful: unveiling the pregnant body. Medische Antropologie 21(1): 53-73.

Waller G (2011) The Virgin Mary in Late Medieval and Early Modern English Literature and Popular Culture. Cambridge: Cambridge University Press. Warner M (1990 [1976]) Alone of All Her Sex: The Myth and the Cult of the Virgin Mary. London: Picador.

Zires M (2005) Los cuerpos des-cubiertos de la Guadalupana. Anuario de investigación 2004. Mexico DF: Universidad Autónoma Metropolitana, 89-107. 